\title{
A Study of Civil Servants CareerDevelopmentfrom the Perspective ofGenderat State PolytechnicofUjung Pandang
}

\author{
Enny Radjab dan Tjare A. Tjambolang \\ ${ }^{1)}$ Lecturers at Business Administration, State Polytechnic of Ujung Pandang, Jl. Perintis Kemerdekaan Km. 10, \\ Tamalanrea,Makassar 90245, Indonesia
}

\begin{abstract}
This researchaims to identify andanalyse the influence ofeducation, skills, work motivation and leadership, either partiallyor simultaneouslyto thecareerdevelopment ofwomencivil servantsin State Polytechnic of Ujung Pandang. The analytical method used is descriptive analysis and inferential statistical analysis; analytical techniquesto test the hypotheses aremultiple regressionmethods. From the results obtained by the regression analysis adjusted Rsquare is 0.210 , which means that $21 \%$ of variation of career development can be explained by the variation of the four independent variables (education, skills, work motivation, and leadership), while the remaining 79\% is explained by other causes beyond models. The results showed that either partiallyor simultaneously independent variables: education, skills, work motivation and leadership significantly influence the career development of women employees in the State Polytechnic of Ujung Pandang.

Key words: career development, education, skills, work motivation, leadership
\end{abstract}

\section{Introduction}

One way to develop and empower human potential in an organization is to foster and improve the qualification of human resources for science and technology master. This will make the human resources capable of carrying out their duties and functions well, able to contribute to the running of the organization, which is based on faith and piety, which in turn is expected to be reliable professional actors. Allocating and empowering human resourcesshould be based on the principle that the accuracy of placement based on the background of the capabilities of human resources, or based on the job analysis without distinguishing the female employeesfrom male employees.

Human resources with good quality are androgynous and very important, and they have a crucial role in the efforts of formulating and implementing policies in the organization. This is because human resources are valuable assets of the organization and play an important role for the continuity of the organizations' life-both government and private organizations.

Gender analysis of social theory that befits such as class analysis, cultural analysis and discourse analysis, is an analytical tool for understanding social reality. Besides the fact that gender analysis helps to understand that the subject matter is a system and structure that is not fair-where the men and women are victims and dehumanization suffered because of the injustice of gender analysis, Dehumanization of women is experienced as a result of gender inequity while men's dehumanization is experienced because of perpetuate gender oppression. Many programs have been carried out by the Government in order to empower women, but if observed, the programs have not given the implications for women as a whole. The programs tend to be designed unclearly. Besides, there is no readiness of policy makers to design programs that really empower women in bigger scope.

With regard to the pattern of development of modern thought about the modernization of international countries, it is known that development is a process that runs in linear, sure progress. But in reality, the position of women is behind/ less attended; in other words the position of women is left behind in the development process-as actors, objects and beneficiaries of development. This happens in almost all countries in the world, especially developing countries.

Why are women lagging behind in development? According Trisaksi (2006:370) backwardness of women in the implementation of development caused by various reasons: both classical and contemporary reasons related to the socio-cultural values. Women in-development approach (woman in development), which leads to the relationship between women and the development process, is not the location of the position discussed.Although there has been an understanding that between men and women in positions, opportunities and roles are aligned. But what about the fact about the position of men and women in development?

The study of the concept of gender analysis in development on an ongoing basis started from the discussion of women in development towards gender. Gender planning is an approach to address gender issues in project, program and development planning process to focus on long-term goals and to assess whether a project is less empowering the potential of women and more dominant in males. 
Until now, research on women is quite prominent because many researchers raised issues that surfaced during the women faced, but not men faced. Critics of the phenomenon based on the fact that women cannot be separated from men because both are in the same social system. In every organization both government and private organizationsplace women in men's position for various reasons without the consideration to base it on different aspects of competence or gender equality. Therefore this developed a range of research focusing on gender.

Employees career development of women as human resources should be aligned with the male employees; this seems to get meager attention. Phenomena that occur on State Polytechnic of Ujung Pandang in terms of gender aspects in the empowerment and development of potential female employees towards their career development are very limited while the employee's career development is very likely for men. In other words, there is no equality between employees career development opportunities for women and men employees

According to these researches, various human factors which need to be assessed in the development of career for any female employee at State Polytechnic of Ujung Pandang include: level of education and leadership. Employee-owned educational level of women as an element of competence is empowered worth as a potential employee owned as men, but what happens is that female employee-owned education is considered unable to contribute optimally to the given tasks. The main reason that women have a less strict attitude especially in making decisions about work-related activities. However, it cannot be used as a reference in enhancing each womanemployee's career, prior to a deeper study of the education of women and their relationship to employee career development. The level of education and perseverance in working of women employees should get a strategic position with a good performance assessment by the leaders, but it is considered that the level of education and the lack of persistence of work contribute to the organization when compared with male employees. Provision of opportunities for continuing education and training are provided to more dominant male employees than female employees.

The presumption against employment as an element of leadership for women employees is not to be equated with a male employee in a particular position despite competence aspect that can be equated with a male employee. Not to position female employees on the job requires the dominant physical ability and potential risks of work, but the position of women employees in positions requiring qualifications is also very limited.

\section{Methods}

The research was conducted at State Polytechnic of Ujung Pandang. The analytical method used is descriptive analysis and inferential statistical analysis, while analytical techniques to test the hypothesis is a multiple regression method. The data in this study are using two sources of data i.e. primary data and secondary data. The population is the entire female civil servants at State Polytechnic of Ujung Pandang, amounting to 205 people, while the number of 132 samples is determined using Krecjie table.

\section{Testing the Multiple Regression}

Regression testing is used to find the influence between variables. The formula of the regression can be formulated as follows:

$\mathrm{Y}=\beta 0+2 \mathrm{X} 2+\beta 1 \mathrm{X} 1+\beta \beta \beta 3 \mathrm{X} 3+4 \mathrm{X} 4+\varepsilon \mathrm{i}$

where

$\mathrm{Y}=$ the career development of women in the civil service PNUP

$\mathrm{X} 1=$ Education

$\mathrm{X} 2=$ Skills

$\mathrm{X} 3=$ Work Motivation

$\mathrm{X} 4=$ Leadership

B $0=$ Constant

ß 1, , 2 , ß 3, , 4 = Coefficient Regression

For more details, operationalization matrix variables can be seen in Table 1 as follows: : 
Table 1. Variable Operationalization Matrix Research

\begin{tabular}{|c|c|c|c|}
\hline Variable & Sub Variable & Indicator & Scale \\
\hline $\begin{array}{l}\text { FactorsaffectingCareer } \\
\text { Development }\end{array}$ & $\begin{array}{l}\text { 1. } \quad \text { Education(X1) } \\
\text { 2. Skills(X2) } \\
\text { 3. Workmotivation(X3) } \\
\text { 4. Leadership(X4) }\end{array}$ & $\begin{array}{l}\text { 1. Qualification } \\
\text { 2. Compliance withemployment } \\
\text { 3. Contribution toemployment } \\
\text { 1. perseverance } \\
\text { 2. proficiency } \\
\text { 3. the pace of work } \\
\text { 1. Awards/recognitionwork } \\
\text { 2. Confidence andjob security } \\
\text { 1. directingthe work } \\
\text { 2. Communicatingthe work } \\
\text { 3. Managerial ability }\end{array}$ & \\
\hline & 5. Carier Development (Y) & $\begin{array}{l}\text { 1. work attitude } \\
\text { 2. work system } \\
\text { 3. performance }\end{array}$ & \\
\hline
\end{tabular}

\section{Hypothesis Testing}

To test the hypothesis of the study, the following techniques are used :

\section{t Test}

$\mathrm{T}$ test was used to test whether the independent variables are individually significant effect on the dependent variable with testing performed at $\alpha=0.05$, with the formulation of the hypothesis as follows: Ho : bi $=0$, meaning that there is no significant relationship between the independent variables on the dependent variable.

$\mathrm{Ha}: \mathrm{bi} \neq 0$, meaning that there is a significant relationship between the independent variables on the dependent variable.

The determination of the decision on the hypothesis with the following criteria:

- Ho: Ha rejected or accepted, if t count is greater than $t$ table, there is the influence of independent variables on the dependent variable individually.

- Ho: Ha rejected or accepted, if the value of $t$ is greater than the value of the probability, there is the influence of independent variables on the dependent variable individually.

test $\mathbf{F}$

$F$ test is done to test the effect of simultaneous independent variables on the dependent variable and indicates whether the variation in the value of the independent variable can explain variation in the dependent variable. Tests were conducted at $\alpha=0.05$ with the formulation of hypotheses as follows:

- Ho : b1 , $2, \ldots . . \mathrm{n}=0$, meaning that there is no significant relationship between the independent variables on the dependent variable simultaneously.

- $\quad \mathrm{Ha}: \mathrm{b} 1,2, \ldots . \mathrm{n} \neq 0$, it means that there is a significant relationship between the independent variables on the dependent variable simultaneously.

The determination of whether a decision on the hypothesis is accepted or rejected can be described as follows:

- When the F value < F table means Ho accepted and Ha is rejected

- When F count $>$ F means that Ho is rejected and Ha accepted.

- When the value of $\mathrm{F}>$ probability value, then Ho is rejected and Ha is accepted--there is the influence of independent variables on the dependent variable partially

\section{Results AndDiscussion}

\section{Description ofResearch Variables}

Frequencydistribution ofscoresis obtained from thetabulation ofrespondents' answers. Thebasicinterpretation of thescoresof itemsin thestudy variablesis describedin the following table: 
Table2. ScoreInterpretationBasicResearchItemInVariable

\begin{tabular}{|c|c|c|}
\hline No. & Score of Value & Interpretasi \\
\hline 1 & $0<\mathrm{SV} \leq 1$ & Beingina verynegativearea \\
\hline 2 & $1<\mathrm{SV} \leq 2$ & Beingina negativearea \\
\hline 3 & $2<\mathrm{SV} \leq 3$ & Beingina middlearea \\
\hline 4 & $3<\mathrm{SV} \leq 4$ & Beingina positivearea \\
\hline 5 & $4<\mathrm{SV} \leq 5$ & Beingina verypositivearea \\
\hline
\end{tabular}

Source: Arikunto, 1998

Descriptionof adescriptivestatisticalanalysisofeach variableis describedasfollows:

\section{Education}

Education variableis measured bythreeindicators, namely: education, (X1.1), compliance withemployment(x1.2), andcontributed to the work(X1.3). Results summaryfrequency distribution ofrespondents' answerstothe itemsofthe attitudevariablesare shown in Table6.4asfollows:

Table3. Frequency Distributionof EducationVariableitems(X1)

\begin{tabular}{|c|c|c|c|c|c|c|c|c|c|c|c|}
\hline \multirow[b]{3}{*}{ Item } & \multicolumn{10}{|c|}{ AnswerScore } & \multirow[b]{3}{*}{ Mean } \\
\hline & \multicolumn{2}{|c|}{1} & \multicolumn{2}{|c|}{2} & \multicolumn{2}{|c|}{3} & \multicolumn{2}{|c|}{4} & \multicolumn{2}{|c|}{5} & \\
\hline & $\mathbf{F}$ & $(\%)$ & $\mathbf{F}$ & $(\%)$ & $\mathbf{F}$ & $(\%)$ & $\mathbf{F}$ & $(\%)$ & $\mathbf{F}$ & $(\%)$ & \\
\hline X1.1 & 1 & 0.76 & 17 & 12.88 & 96 & 72.73 & 9 & 6.82 & 9 & 6.82 & 3.06 \\
\hline $\mathrm{X} 1.2$ & 28 & 21.2 & 16 & 12.1 & 8 & 6.1 & 46 & 34.8 & 34 & 25.8 & 3.32 \\
\hline $\mathrm{X} 1.3$ & 24 & 18.2 & 23 & 17.4 & 16 & 12.1 & 48 & 26.4 & 21 & 15.9 & 3.14 \\
\hline
\end{tabular}

Source : PrimaryData processed(2012)

Based on Table 3, it can be seen that of the 132 respondents surveyed, respondents' perceptions of general education (X1) is in the positive region with an average score of 3.17 and is otherwise good. Indicators obtaining the highest response is the level of education (X1.1), with an average score of 3.06; further indicator of the suitability of the work (x1.2), with an average score of 3.32 , and the last indicator is a contribution to the work (X1.3), with an average score of 3.14. This illustrates that the level of education owned by an employee will be able to develop and facilitate the implementation of various programs of work that are expected as a manifestation of its competence, and employee education is held in accordance with the work.

\section{Skills}

Skills variables measured by three indicators, namely: perseverance, (X2.1), skills, (X2.2), and the pace of work and (X2.3). Results summary frequency distribution of respondents' answers to the items of variable skill can be seen in Table 4, as follows:

Table 4. Distribution of Variable Frequency Items Skills (X2)

\begin{tabular}{|c|c|c|c|c|c|c|c|c|c|c|c|}
\hline \multirow[b]{3}{*}{ Item } & \multicolumn{10}{|c|}{ Answer Score } & \multirow[b]{3}{*}{ Mean } \\
\hline & \multicolumn{2}{|c|}{1} & \multicolumn{2}{|c|}{2} & \multicolumn{2}{|c|}{3} & \multicolumn{2}{|c|}{4} & \multicolumn{2}{|c|}{5} & \\
\hline & $\mathbf{F}$ & $(\%)$ & $\mathbf{F}$ & $(\%)$ & $\mathbf{F}$ & $(\%)$ & $\mathbf{F}$ & $(\%)$ & $\mathbf{F}$ & $(\%)$ & \\
\hline $\mathrm{X} 2.1$ & 19 & 14.4 & 28 & 21.2 & 14 & 10.6 & 52 & 39.4 & 19 & 14.4 & 3.18 \\
\hline $\mathrm{X} 2.2$ & 32 & 24.2 & 28 & 21.2 & 15 & 11.4 & 46 & 34.8 & 11 & 8.3 & 2.82 \\
\hline $\mathrm{X} 2.3$ & 8 & 6.1 & 26 & 19.7 & 22 & 16.7 & 52 & 39.4 & 24 & 18.2 & 3.44 \\
\hline
\end{tabular}

Source : Primery Data processed (2012)

Based on Table 4 , it can be seen that of the 132 respondents surveyed respondents' general perception skills ( X2 ) are in the positive region with an average score of 3.15 and is otherwise good . Indicators obtaining the highest responseis timeliness female employees in work ( X2.3 ), with an average score of 3.44, further indicators of diligence in the work of women employees (X2.1), and a female employee skills (X2. 2), with an average score of 2.82. It describes a condition in which women employees in the work of the time, so the work is always completed on time. In addition to being on-time, female employees are also diligent and competent in working. 


\section{Work Motivation}

Variable work motivation was measured by three indicators, namely: having a strong willingness to work because they want to get an award for his work (X3.1), and having a strong confidence on the implementation of assigned work (X3.2). Results summary frequency distribution of respondents' answers to the items of work motivation variables can be seen in Table 5 as follows:

Table 5. Frequency distribution of variable items work motivation (X3)

\begin{tabular}{|c|c|c|c|c|c|c|c|c|c|c|c|}
\hline \multirow[b]{3}{*}{ Item } & \multicolumn{10}{|c|}{ Answer Score } & \multirow[b]{3}{*}{ Mean } \\
\hline & \multicolumn{2}{|c|}{1} & \multicolumn{2}{|c|}{2} & \multicolumn{2}{|c|}{3} & \multicolumn{2}{|c|}{4} & \multicolumn{2}{|c|}{5} & \\
\hline & $\mathbf{F}$ & $(\%)$ & $\mathbf{F}$ & $(\%)$ & $\mathbf{F}$ & $(\%)$ & $\mathbf{F}$ & $(\%)$ & $\mathbf{F}$ & $(\%)$ & \\
\hline X3.1 & 9 & 6.8 & 23 & 17.4 & 20 & 15.2 & 64 & 48.5 & 16 & 12.1 & 3.42 \\
\hline $\mathrm{X} 3.2$ & 7 & 5 & 15 & 11 & 16 & 12.12 & 74 & 56 & 20 & 15 & 3.64 \\
\hline
\end{tabular}

Source : Primery Data processed (2012)

Based on Table 5, it can be seen that the 132 respondents surveyed respondents' general perception of work motivation (X3) are in the positive region with an average score of 3.53 and is otherwise good. Indicators obtainingthe highest response is to have a strong confidence that the execution of the work assigned (X3.2), with an average score of 3.64; then followed by the indicator that has a strong willingness to work because they want to get an award for his work (X3.1) with a mean score of 3.42. This suggests that female employees have high motivation to work where it is shown through self-confidence and a strong will to work to earn the award for their work.

\section{4 . Leadership}

Leadership variable is measured by three indicators, namely: direct (X4.1), communicate job (X4.2) and managerial ability (X4.3). Results summary frequency distribution of respondents' answers to the items of the variables of leadership can be seen in Table 6 as follows:

Table 6. Distribution of Variable Frequency Items Leadership (X4)

\begin{tabular}{|c|c|c|c|c|c|c|c|c|c|c|c|}
\hline \multirow[b]{3}{*}{ Item } & \multicolumn{10}{|c|}{ Answer Score } & \multirow[b]{3}{*}{ Mean } \\
\hline & \multicolumn{2}{|c|}{1} & \multicolumn{2}{|c|}{2} & \multicolumn{2}{|c|}{3} & \multicolumn{2}{|c|}{4} & \multicolumn{2}{|c|}{5} & \\
\hline & $\mathbf{F}$ & $(\%)$ & $\mathbf{F}$ & $(\%)$ & $\mathbf{F}$ & $(\%)$ & $\mathbf{F}$ & $(\%)$ & $\mathbf{F}$ & $(\%)$ & \\
\hline $\mathrm{X} 4.1$ & 9 & 6.8 & 23 & 17.4 & 22 & 16.7 & 67 & 50.8 & 11 & 8.3 & 3.36 \\
\hline $\mathrm{X} 4.2$ & 15 & 11.4 & 20 & 15.2 & 21 & 15.9 & 64 & 48.5 & 12 & 9.1 & 3.29 \\
\hline $\mathrm{X} 4.3$ & 7 & 5.3 & 20 & 15.2 & 33 & 25.0 & 51 & 38.6 & 21 & 15.9 & 3.45 \\
\hline
\end{tabular}

Source: Primary Data processed (2012)

Based on Table 6, it can be seen that the 132 respondents surveyed generally respondents' perceptions of leadership (X4) are in the positive region with an average score of 3.37, and it is otherwise good. Indicators obtaining the highest response was to have the managerial capability (X4.3), with an average score of 3.45; then followed by the indicator to be able to affect to be more effective in the work (X4.1) with a mean score of 3.36, and the last indicator is to be able to communicate the work (X4.2), with an average score of 3.29. This suggests that female employees have demonstrated exceptional leadership managerial ability, then female employees may also affect other employees to be more focused task/work charged and female employees are also better in being able to communicate their work to others.

\section{Career Development}

Leadership variable is measured by three indicators, namely: work attitude (Y1.1), the working system (Y1.2) and performance (Y1.3). Results summary frequency distribution of respondents' answers to the items of the career development variables can be seen in Table 7 as follows: 
Table 7. Frequency distribution Items Career Development Variables (Y1)

\begin{tabular}{|c|c|c|c|c|c|c|c|c|c|c|c|}
\hline \multirow[b]{3}{*}{ Item } & \multicolumn{10}{|c|}{ Answer Score } & \multirow[b]{3}{*}{ Mean } \\
\hline & \multicolumn{2}{|c|}{1} & \multicolumn{2}{|c|}{2} & \multicolumn{2}{|c|}{3} & \multicolumn{2}{|c|}{4} & \multicolumn{2}{|c|}{5} & \\
\hline & $\mathbf{F}$ & $(\%)$ & $\mathbf{F}$ & $(\%)$ & $\mathbf{F}$ & $(\%)$ & $\mathbf{F}$ & $(\%)$ & $\mathbf{F}$ & $(\%)$ & \\
\hline $\mathrm{Y} 1.1$ & 14 & 10.6 & 34 & 25.8 & 31 & 23.5 & 35 & 26.5 & 18 & 13.6 & 3.07 \\
\hline $\mathrm{Y} 1.2$ & 6 & 4.5 & 22 & 16.7 & 38 & 28.8 & 58 & 43.9 & 8 & 6.1 & 3.30 \\
\hline $\mathrm{Y} 1.3$ & 4 & 3.0 & 20 & 15.2 & 29 & 22 & 65 & 49.2 & 14 & 10.6 & 3.49 \\
\hline
\end{tabular}

Source : Primery Data processed (2012)

Based on Table 7, it can be seen that the 132 respondents surveyed generally respondents' perceptions of career development (Y) are in the positive area with an average score of 3.29 and is otherwise good. Indicators obtaining the highest response was performance (Y1.3), with an average score of 3.49; then it is followed by the indicator system work (Y1.2) with an average score of 3.30, and the last indicator is being capable of work attitude (Y1.1), with an average score of 3.07. This shows that the performance of female employees indicated by the quantity and quality of work are in accordance with the standard of work that has been set, then the female staffs work directly with the implications of existing work systems at State Polytechnic of Ujung Pandang, and female employees working attitude gives positive implications on the job.

Test Validity

\section{Test Research Instruments}

Validity test aims to determine the degree of validity of the instruments used in the study. Through the validity of the test, it will be known whether the items presented in the questionnaire question are really able to reveal with certainty the problem under study. As for how to test the validity of using Product Moment formula with a significant level of 0.05 . If rxy > table then the data is valid, but if rxy < table then the data is invalid. Validity can also be known from the results of the significance of the correlation, if the significance of the results is smaller correlation of 0.05 , then the test is a powerful construct. Based on the data obtained in the study, the results of testing the validity of the research instruments are asfollows:

Table 8. Recapitulation of Validity and Reliability Test Results

\begin{tabular}{|c|c|c|c|c|c|c|}
\hline Variable & Item & $\mathbf{r}$ & Sig. & Note & Reliabilitas & Note \\
\hline \multirow{3}{*}{$\begin{array}{l}\text { Education } \\
\text { (X1) }\end{array}$} & $\mathrm{X} 1.1$ & 0.824 & 0.048 & Valid & \multirow{3}{*}{0.651} & \multirow{3}{*}{ Reliable } \\
\hline & $\mathrm{X} 1.2$ & 0.823 & 0.000 & Valid & & \\
\hline & $\mathrm{X} 1.3$ & 0.173 & 0.000 & Valid & & \\
\hline \multirow{3}{*}{ Skill (X2) } & $\mathrm{X} 2.1$ & 0.837 & 0.000 & Valid & \multirow{3}{*}{0.621} & \multirow{3}{*}{ Reliable } \\
\hline & $\mathrm{X} 2.2$ & 0.851 & 0.000 & Valid & & \\
\hline & $\mathrm{X} 2.3$ & 0.553 & 0.000 & Valid & & \\
\hline \multirow{2}{*}{ Work motivation(X3) } & $\mathrm{X} 3.1$ & 0.783 & 0.000 & Valid & \multirow{2}{*}{0.786} & \multirow{2}{*}{ Reliable } \\
\hline & $\mathrm{X} 3.2$ & 0.744 & 0.000 & Valid & & \\
\hline \multirow{3}{*}{ Leadership (X4) } & $\mathrm{X} 4.1$ & 0.805 & 0.000 & Valid & \multirow{3}{*}{0.677} & \multirow{3}{*}{ Reliable } \\
\hline & $\mathrm{X} 4.2$ & 0.776 & 0.000 & Valid & & \\
\hline & $\mathrm{X} 4.3$ & 0.760 & 0.000 & Valid & & \\
\hline \multirow{3}{*}{ Career development $(\mathrm{Y})$} & Y1.1 & 0.832 & 0.000 & Valid & \multirow{3}{*}{0.719} & \multirow{3}{*}{ Reliable } \\
\hline & Y1.2 & 0.800 & 0.000 & Valid & & \\
\hline & Y1.3 & 0.776 & 0.000 & Valid & & \\
\hline
\end{tabular}

Source : Primery Data processed (2012)

Based on Table 8, it can be seen that the research instruments for all sub dimensions and variables are valid.

\section{Test Reliability}

Reliability is an index that indicates the extent to which a measuring instrument can be trusted or relied upon. A new measuring instrument can be trusted and relied upon to always obtain consistent results from the measurement of symptoms that do not change at different times. To perform reliability test, Cronbach Alpha, where a research instrument said to be reliable if it has a social need or alpha coefficient of 0.6 or more, can be used. 
Based on the results of testing the reliability of the research instruments, as listed in Table 8 , the test results showed that the entire research instrument is reliable. It can be seen that all the variables of this study have alpha coefficients greater than 0.6. When the results of the reliability test criteria associated with the coefficient of reliability index according Arikunto (1998), showed that the alpha coefficient was high research instruments. Thus the data is valid, and feasible research can be used to test the research hypothesis.

\section{Multiple Linear Regression Analysis}

\section{Results}

Multiple regression analyses were conducted to prove the hypothesis proposed in this study, namely to analyze the effect of independent variables on the dependent variable, either partially or simultaneously as well as to test the research hypotheses that have been proposed previously.

The basic test of this hypothesis is using both the probability value for the test partially and simultaneously. In general, the hypothesis put forward in this study are as follows:

Ho: $\quad$ There is no effect of independent variables on the dependent variable

Ha: There is the influence of independent variables on the dependent variable

Basic decision -makings are:

$\leq 0.05$, then Ho is rejected $\alpha$

$\alpha>0.05$, then Ho is accepted

Hypothesis testing is done with a simple regression statistical analysis techniques that are standardized, of the processed sub computer program SPSS for Windows that will be presented through tables of significance, the following explanation is consistent with the hypothesis that has been formulated.

Table 9. The results of the regression analysis of the influence of education, skills, work motivation and leadership to career development.

\begin{tabular}{|l|c|c|c|c|c|}
\hline \multicolumn{1}{|c|}{ Variables } & B & Beta & T & Sig t & Note \\
\hline Education $\left(\mathrm{X}_{1}\right)$ & 0.270 & 0.266 & 3.362 & 0.001 & Significant \\
\hline Skills $\left(\mathrm{X}_{2}\right)$ & -0.059 & -0.068 & -0.849 & 0.398 & Not Significant \\
\hline Work Motivation $\left(\mathrm{X}_{3}\right)$ & 0.296 & 0.191 & 2.330 & 0.021 & Significant \\
\hline Leadership $\left(\mathrm{X}_{4}\right)$ & 0.265 & 0.270 & 3.261 & 0.001 & Significant \\
\hline Konstanta & $\mathbf{7 . 3 4 5}$ & & $\mathbf{4 . 8 7 6}$ & $\mathbf{0 . 0 0 0}$ & \\
\hline
\end{tabular}

Source : Primery Data processed (2012)

$\mathrm{R} \quad: \quad 0,484$

R square : $\quad 0,234$

Adjusted $\mathrm{R}$ square $\quad$ : $\quad 0,210$

Alpha : $\quad 0,05$

$\mathrm{F}_{\text {count }}: \quad$ : $\quad 9.696$

Sig F : 0,000

\section{Model Summary}

- The rate $\mathrm{R}$ of 0.484 shows that the correlation or relationship between the dependent variable with the independent variables is strong.

- Figures R-square or the coefficient of determination was 0.234 . Adjusted R square is 0.210 . This means that $21 \%$ of the variation of career development can be explained by variations of the four independent variables (education, skills, work motivation, and leadership), while the remaining $79 \%$ is explained by other causes outside the model.

- Standard Error of Estimate ( SEE ) is 2,272. The smaller the SEE will make more precise regression model predicting the dependent variable.

The results of the regression equation are as follows:

$\mathrm{Y}=7,345+0.270 \mathrm{X} 1-0.059 \mathrm{X} 2+0.296 \mathrm{X} 3+0.265 \mathrm{X} 4+\dot{\varepsilon}$

Regression coefficient of the independent variable that is positive indicates that there is a positive relationship with the dependent variable. This means no increase in any of the variables of education, work motivation, and leadership that will lead to a rise in the career development variables. While the independent negative variables indicate that there is a negative relationship with the dependent variable--every increment of variable skill causes a decrease in the career development variables. 


\section{Hypothesis Testing}

a. Suspected variable education, skills, work motivation and leadership will partially affect career development.

After testing through multiple regression analyses of all independent and dependent variables partially, ie: $\mathrm{X} 1, \mathrm{X} 2, \mathrm{X} 3, \mathrm{X} 4$ and $\mathrm{Y}$, it turned out that the education variable (X1) has a significant influence on the development of career ( $\mathrm{Y}$ ) where the significance of $\mathrm{t}$ has a value of 0.001<0:05. So education is partially significant effect on career development.

Skill variable (X2) gives significant influence on career development (Y) which has a value of significance t $0398>0: 05$--the partial skill effect is not significant to the development of career.

Work motivation variable (X3) has a significant influence on the development of career (Y) which has a value of $0.021 \mathrm{t}$ significance of $<0.05$. So the motivation to work has partially significant effect on career development.

Leadership variablehas a significant influence on the development of career ( $Y$ ) where t has a significance value $0.001>0.05$ level-- partially leadership significantly influence career development.

b. Factors of education, skills, work motivation, and leadership will simultaneously affect career development.

After testing through multiple regression analysis of all independent and dependent variables simultaneously, ie: $\mathrm{X} 1, \mathrm{X} 2, \mathrm{X} 3, \mathrm{X} 4$ and $\mathrm{Y}$, it turns out that independent variables $(\mathrm{X} 1, \mathrm{X} 2, \mathrm{X} 3$, and $\mathrm{X} 4$ ) have a significant influence on the development of career $(\mathrm{Y})$ where $\mathrm{F}$ has a significance value of $0.000>0.05$. While Adjusted R2 of 0.210 or contributions made variable $(\mathrm{X})$ on the career development variables $(\mathrm{Y})$ is equal to $21 \%$, so there is no contribution from the other variable that is equal to $79 \%$.

Based on the above information, the hypothesis is accepted, while the calculations to determine the recapitulation can be seen in Table 10, as follows:

Table 10. Recapitulation and Testing Regression Coefficients Between Variables In Simultaneous X and Y

\begin{tabular}{|c|c|c|c|c|c|c|c|}
\hline $\begin{array}{c}\text { Bound } \\
\text { Variabel }\end{array}$ & Free Variabel & $\mathrm{R}$ & $\mathrm{R}^{2}$ & Adjusted $\mathrm{R}^{2}$ & $\mathrm{~F}$ & Sign. & Conclusion \\
\hline $\mathrm{Y}$ & $\mathrm{X}$ & 0.484 & 0.234 & 0.210 & 9.696 & 0.000 & Significant \\
\hline
\end{tabular}

Source:Primary Data processed (2012)

\section{TestingAssumptionsClassic}

Toobtainunbiased estimatorvaluesandmore efficientthanamultiple regressionequation, the datamust meetthe followingcriteriaof classicalassumptions:

\section{Multicollinearity}

Multicollinearityis asituation wherethere is avery high correlationbetween theindependent variablein the regression equation. According toGujarati(1999) multicollinearitymeansa high correlation(close to perfect) betweenthe freevariables. Todetectthe presence or absenceof multicollinearityis doneby looking at theVIF(Variance InflatingFactor), if theVIF valueis lessthan5, then the model does nothappen asMulticolinerity(Santoso, 2003).

Table 11.Multicolinierity test

\begin{tabular}{|c|c|c|c|}
\hline Independent Variable & Tolerance & VIF & Keterangan \\
\hline Education & 0.963 & 1.038 & Non Multicolinierity \\
\hline Skills & 0.949 & 1.053 & Non Multicolinierity \\
\hline Work Motivation & 0.894 & 1.119 & Non Multicolinierity \\
\hline Leadership & 0.878 & 1.139 & "Non Multicolinierity \\
\hline
\end{tabular}

Source : Primery Data processed (2012)

Based on Table 11, it is known that no VIF value that exceeds the value of 5, thus it can be concluded that there is no multicollinearity.

\section{Heterocedasticity}

Heterokedasticity will result in the assessment of regression coefficients to be inefficient. The results of the assessment will be less than it should be. Heterokedasticity contradicts one of the basic assumptions of linear regression, namely that the same residual variation for all observations or called homoskedasticity (Gujarati, 1999). The diagnosis can be made with regard to heterokedastisitas residuals (* ZRESID) and predicted variables (* ZPRED). If the distribution point in plots scattered around zero ( 0 on the $\mathrm{x}$-axis) and does not form a particular pattern or trend line, it can be said that the model did not meet the assumptions of the regression 
model said heterokedastisitas or qualified to predict (Santoso, 2003). Heterokedastisitas tested using the scatterplot graph. Heteroscedasticity test results are shown in the figure below.

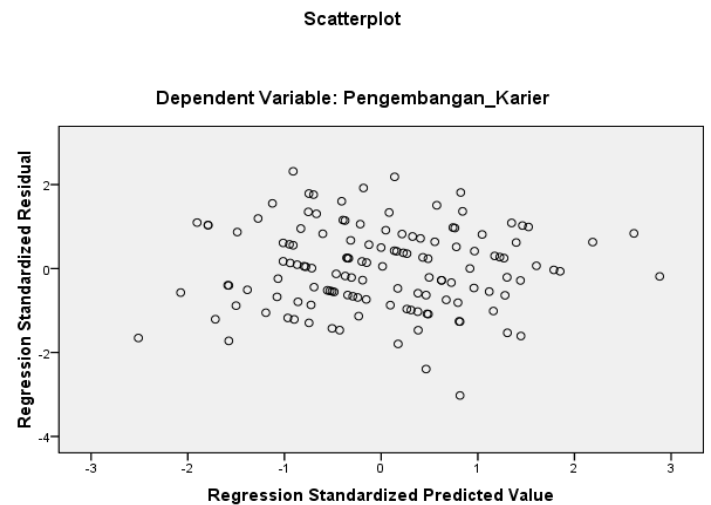

Source: Primary Data processed (2012)

Based onthe abovepicture, it can be seenthat there is noheteroscedasticitybecausethere is noclear pattern, andthe pointsare spread. Thebases for decision makingare:

1) Ifthere arecertainpatternsthat forma particularpatternof regularity, then there isheteroscedasticity

2) If there is noclear pattern, andthe pointsare spread, there is noheteroscedasticity.

\section{Autocorrelation}

Todetectthe presence or absenceof autocorrelationtheDurbin-Watson testis done(DW) with the following conditions:

a. $1.65<\mathrm{DW}<2.35$ meaning noautocorrelation

b. $1.21<\mathrm{DW}<1.65$ or $2.35<\mathrm{DW}<2.79$ then it cannotbe concluded

c. $\mathrm{DW}<1.21$ orDW $>2.79$ then theautocorrelation

Table 12. Autocorrelation

\begin{tabular}{l|r|r|r|r|r|}
\hline Model & \multicolumn{1}{|c|}{ R } & R Square & Adjusted R Square & $\begin{array}{c}\text { Std. Error of the } \\
\text { Estimate }\end{array}$ & Durbin-Watson \\
\hline 1 & $.484^{\mathrm{a}}$ & .234 & .210 & 2.272 & 2.026 \\
\hline
\end{tabular}
a. Predictors: (Constant), Education, Skills, Work Motivation, Leadership
b. Dependent Variable: Carrier Development

Source: Primary Data processed (2012)

From Table 12. known that the Durbin - Watson value is 2.026 . This means that the model is free from the problem of autocorrelation.

\section{Normality}

Normality test is used to detect whether the data distribution of independent variables and the dependent variable is normal. Normality test was intended to see whether the data are analyzed to have a residual value to be around zero ( normal data ) or not. If you were around zero, then the assumption of normality is met, and vice versa (Santoso, 2003). Regression model is having a good data distribution that is normal or near normal. To test the normality or detect this, it is known from the normal probability plot display. If the data spread around the diagonal line and follow the direction of the diagonal line, then the regression model to meet the assumption of normality. However, if the data are spread away from the diagonal line and/or do not follow the direction of the diagonal line, then the regression model does not meet the assumption of normality.

Based on the normal probability plot graph is shown in the following figure: 
Figure 2. Graph Normal Probability Plot

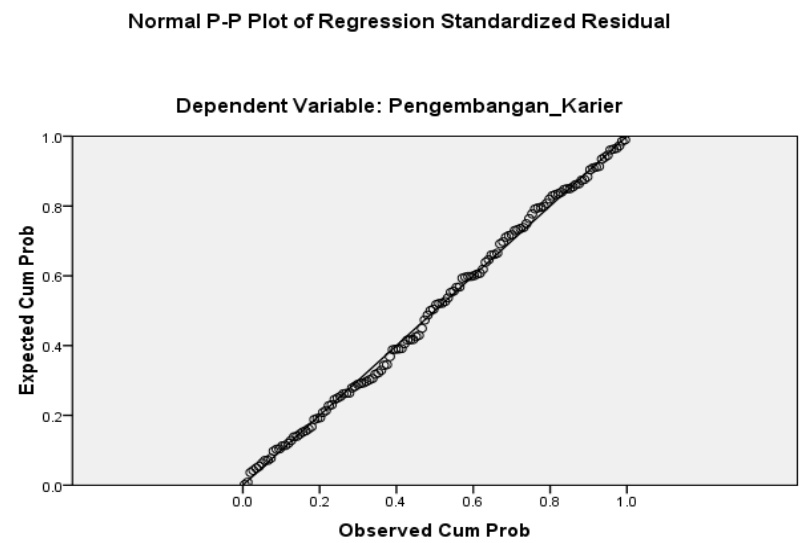

Source: Data processed (2012)

From this figure, it is seen that the points spread around the diagonal line, and its distribution follows the direction of the diagonal line. So that the regression model used to predict the development of viable career based on input independent variable.

\section{Discussion}

Based on the results of tests that have been done, it turns out that the hypothesis is accepted due to partial or simultaneous independent variables: education, skills, work motivation and leadership significantly that influence the career development of female employees at the Polytechnic of Ujung Pandang.

Partially educational factors significantly influence the career development of women employees. This suggests that the education of women-owned employee can contribute optimally to the task - the task given. Female employees devise their careers in order to improve their status or position in a job. In planning the career employees, they may take advantage of opportunities for self-development to increase their knowledge through education.

Furthermore, there is no significant effect skill factor to employee career development of women. This suggests that the skills possessed by female employees as an element of competency must be empowered as a potential employee owned as men. Therefore, the skills possessed by women employees are not made in order to develop their careers. Nevertheless female employees work more diligently and more capably, and they are very concerned about the time.

Work motivation factors significantly influence the career development of women employees. This suggests that the female employee motivation shown through a strong willingness to work because they want to get an award for her work and has a strong confidence on the implementation of assigned work that will affect her career development. Female employees who have high work motivation will have a positive perception and evaluation of their career.

Leadership factors significantly influence employee career development of women. The attitude of the leadership shown by the attitude that can affect other employees to be more effective in carrying out the tasks and work more female employees can communicate job duties to other employees. Also, female employees have the managerial skills to achieve a common goal. Under the leadership attitudes held by the female employee, their career development may make it easier in the future.

Simultaneously educational factors, skills, work motivation and leadership affect significantly to the career development of women employees. These results indicate that the female employee career development can be obtained through increased levels of education and skills, work motivation and attitudes of leadership; it can encourage the role of women in developing and utilizing advanced science and technology in development.

\section{Conclusion}

\section{Conclusions And Suggestions}

1) Partially, education significantly influence employee career development of women.

2) Partially, skills do not influence significantly to the career development of women employees.

3) Partially, work motivation significantlyaffects on employee career development of women.

4) Partially, leadership significantly influences employee career development of women.

5) Simultaneously, education, skills, work motivation and leadership significantly influence employee career development of women. 


\section{Suggestion}

Based on the analysis and discussion, it can be argued that some of the suggestions can be taken into consideration both for researchersand institutions.

1) The position of women employees should be based on consideration of aspects of the competency of the employee, for example level of education, work motivation, and leadership.

2) Employee career development of women as human resources should be aligned with male employees.

3) There should be equality of opportunity for career development among female employees and male employees.

\section{Bibliography}

[1] Achmad S, 1992, Kebijaksanaan Peningkatan Peranan Wanita da/am Perspekti/ Pendidikan, Bandung Humaniora Utama Press

[2] Anwar, 2006, Manajemen Pemberdayaan Perempuan, Penerbit Alfabeta Bandung

[3] Davis, 1997, Perilaku Organisasi, Terjemahan Agus Darma, Jakarta, Erlangga

[4] Hasibuan, P.S. Malayu. 1997. Manajemen Sumber Daya Manusia. Edisi Revisi. Bumi Aksara. Jakarta.

[5] Madura, 2000, Management 7, Edition, Me. Graw Hill, Book Company, Tokyo

[6] Mangkuprawira Anwar Prabu, 2004, Manajemen Sumber Daya Manusia Perusahaan, PT. Remaja Rosdkarya, Bandung

[7] Mathis, Robert, L dan Jackson, 2002, Manajemen Sumber Daya Manusia. Edisi Pertarna, Salemba empat, Jakarta .

[8] Nawawi, H.H. 2000. Manajemen Sumber Daya Manusia. Untuk Bisnis Yang Kompetitif. Cetakan Keenam. Gajah Mada University Press. Jogyakarta.

[9] Schuler Randall and Jackson, 1999, Pengembangan Sumber Daya Manusia Menghadapi Abad KeXXI, Alih bahasa Nurdin Sobari, Erlangga, Jakarta

[10] Sedarmayanti,2001, Sumber Daya Manusia dan Produktivitas 'Kerja, Penerbit Mandar Maju, Bandung

[11] Siagian,Sondang P. 1999. Manajemen Sumber Daya Manusia, Bumi Aksara Jakarta.

[12] Simamora, Henry. 2004. Manajemen Sumber Daya Manusia. Edisi Ketiga. STIE YKPN. Yogyakarta.

[13] Sugiyono. 2002, Statistika untuk Penelitian, Penerbit Alfabeta, Bandung

[14] Sumego,2001, Motivasi dalam Sumber Daya Manusia, PT. Grafindo Persada, Jakarta

[15] Suryadi, 1999, Manajemen Sumber daya Manusia, Kebijaksanaan Kinerja Karyawan, BPFE, Bandung

[16] Sutarto, 2001, Manajemen Sumber Daya Manusia Kebijaksanaan Kinerja Karyawan, BPFE,Bandung

[17] Syahrir, 1999, Manajemen dan Birokrasi, Penerbit Erlangga, Jakarta

[18] Tahir Nur Alam, 2001, Analisis Pengembangan Karier Pegawai Negeri Sipil pada Dinas Lingkup Pemerintahan Daerah Sulawesi Selatan, Makassar

[19] Timpe, Dale A. 1999. Manajemen Sumber Daya Manusia, Memimpin Manusia, Alex Media Komputindo, Jakarta.

[20] Trisakti Handayani, 2006, Konsep dan Teknik Penelitian Gender, Penerbit PT. Penerbitan Universitas Muhammadiayh Malang

[21] Umar, N. 2000. Argumen Kesetaraan Gender Perspektif Al Quran. Jakarta : Paramadina.

[22] Winardi, 1995, Kepemimpinan Suatu Tinjauan Teori, Penerbit PT. Raja Grafindo Persada, Jakarta

[23] YukL, 2000, Kepemimpinan pegawai Negeri Sipil, PT. Gunung Agung, Jakarta 